\title{
LOW COST PRODUCTION AND PURIFICATION OF POLYCLONAL ANTIBODIES TO STAPHYLOCOCCAL ENTEROTOXIN A
}

\author{
Tereza Cristina R.M. de Oliveira*; Elisa Yoko Hirooka
}

Universidade Estadual de Londrina, Departamento de Tecnologia de Alimentos e Medicamentos, CCA, Londrina, Paraná, Brasil

Submitted: March 31, 1997; Returned to authors for corrections: March 16, 1998. Approved: April 08, 1999

\begin{abstract}
An immunization scheme for production of antiserum to staphylococcal enterotoxin A (SEA) is proposed. The reference method of Robbins and Bergdoll was modified to reduce the number of doses and the amount of toxin used per animal. The best immunization scheme used injections in days $0,8,24,59,62$ and 67 . The amount of toxin at each injection was 5, 6, 20,50,100 and $200 \mu \mathrm{g}$, respectively. The total amount of toxin was $381 \mu \mathrm{g}$, which corresponded to a reduction of $107 \mu \mathrm{g}$ in the amount of toxin for each animal when compared to the reference method. The average antiserum titer using the Optimum Sensitivity Plate - OSP was 1:60 and using ELISA the titer was 1:100.000. The lack of cross-reactivity with other staphylococcal enterotoxins indicated high specificity of the antibody to SEA. The proposed immunization scheme was adequate to produce specific SEA antisera, with high titers and the aditional advantage of reducing the amount of purified SEA required for immunization.
\end{abstract}

Key words: Staphylococcus aureus, enterotoxins, detection, immunization

\section{INTRODUCTION}

Staphylococcal food poisoning is a worldwide intoxication caused by the ingestion of staphylococcal enterotoxins (SEs), preformed in food by some Staphylococcus aureus strains. Although $S$. aureus can be easily detected in foods, neither its presence necessarily indicates enterotoxin production nor the absence of viable staphylococci assures food safety (4).

The organism looses viability rapidly after the stationary phase, being replaced by harmless saprophytic bacteria. However, the toxins resist both heat treatment and proteolytic enzymes action and they can be detected in precooked, pasteurized and manufactured foods. The direct detection of enterotoxins in foods requires development of practical, rapid and sensitive assays. Currently, the best methods for enterotoxin identification and quantification depend on the availability of specific antibodies for each enterotoxin type. Immunological methods with monoclonal and polyclonal antibodies for the enterotoxin detection at the level of 1 - $2 \mathrm{ng} \mathrm{g}^{-1}$ include radioimmunoassay, enzyme-linked immunoassay (ELISA) and reversed passive latex agglutination $(5,7,15)$. At least, five diagnostic kits are now available commercially $(9$, $10,14)$.

\footnotetext{
* Corresponding author. Mailing address: Universidade Estadual de Londrina, Departamento de Tecnologia de Alimentos e Medicamentos, CCA, CEP 86051-970, Londrina, Paraná, Brasil, Fax (+5543) 371-4079.
} 
Brazilian Public Health Laboratories have reported many outbreaks of food poisoning involving foods contaminated by $S$. aureus (8). However, the cost of imported diagnostic kits creates difficulties to the use of the direct enterotoxin detection techniques in the routine quality control laboratories.

This work reports an immunization scheme for the production of polyclonal anti-staphylococcal enterotoxin $\mathrm{A}$, simplifying the reference procedure of Robbins and Bergdoll (12) and also describes a simple IgG purification method.

\section{MATERIALS AND METHODS}

\section{Enterotoxins}

Purified enterotoxin A (SEA) for animal immunization was kindly donated by Dr Merlin S. Bergdoll (University of Wisconsin, U.S.A.). Purified enterotoxins $\mathrm{B}(\mathrm{SEB}), \mathrm{C}_{2}\left(\mathrm{SEC}_{2}\right), \mathrm{D}(\mathrm{SED})$ and $\mathrm{E}(\mathrm{SEE})$ for measurement of cross-reactions were acquired from Toxin Technology INC, Madison, Wisconsin, U.S.A.

\section{Preparation of antigen}

Complete Freund's adjuvant was used in the initial injections and incomplete Freund's adjuvant for subsequent procedures. Incomplete adjuvant was prepared mixing $8.5 \mathrm{ml}$ of nujol (Vetec Química Fina Ltda.) with $1.5 \mathrm{ml}$ of lanolin (Quimidrol Com. Ind. Imp. Ltda.), while for complete Freund's adjuvant, $10 \mathrm{mg}$ of freeze-dried avirulent Mycobacterium tuberculosis strain $\mathrm{H} 37 \mathrm{Ra}$ was added to the nujol and lanolin mixture. The toxin dose in $1.0 \mathrm{ml}$ of 0.05 M phosphate buffered saline $\mathrm{pH} 7.4$ was added to 1.0 $\mathrm{ml}$ of Freund's adjuvant and injected subcutaneously into the three different sites of rabbit shoulder.

\section{Immunization scheme}

Anti-SEA was prepared in female New Zealand white rabbits of 2 to $3 \mathrm{~kg}$, using four modifications of the reference procedure (12) (Table 1). One to five rabbits were used for each immunization. The animals were weighed before each injection and every day on the following two days to check for the weight loss (up to $200 \mathrm{~g}$ ). The next injection was postponed, if the weight loss was not regained by the scheduled date.

\section{Determination of antibody titer}

The antiserum titer was determined by the
Optimum Sensitivity Plate (OSP) method (11), using two-fold dilutions of the test serum and the SEA standard at $2 \mu \mathrm{g}$ and $4 \mu \mathrm{g} / \mathrm{ml}$. Blood was taken from the marginal ear vein eight days after the last immunization dose.

\section{Boostering procedure}

The threshold injections were followed with three booster injections on days 63, 66 and 77 after the first injection for the Robbins and Bergdoll's procedure, and on days 59, 62 and 67 for the modified scheme (Table 1). Only rabbits with normal weight and with serum titers of 8 or more received booster injections. Animals with lower than 8 serum titers were discarded. Six weekly bleedings were done starting at week 1 after the last injection.

\section{Antibody purification}

The purification of the IgG fraction of the pooled antisera was carried out using a staphylococcal protein A-Sepharose CL-4b column (Pharmacia). $10 \mathrm{ml}$ of serum was applied onto the column $(5.0 \mathrm{x}$ $1.5 \mathrm{~cm}$ ) at room temperature, washed twice with 0.2 M PBS, $\mathrm{pH} 7.4$ and the IgG fraction was eluted at $4^{\circ} \mathrm{C}$ with $15 \mathrm{ml}$ of $0.1 \mathrm{M}$ sodium citrate buffer, $\mathrm{pH}$ 2.8. The $\mathrm{pH}$ of each fraction was adjusted to 7.0 adding $30 \mu \mathrm{l}$ of $1.0 \mathrm{M}$ TRIS buffer, $\mathrm{pH} 8.8$. Fractions showing the higher absorbances at $280 \mathrm{~nm}$ were pooled and dialysed overnight at $4^{\circ} \mathrm{C}$ against 0.02 $\mathrm{M}$ PBS, $\mathrm{pH}$ 7.4. Protein content was measured according to the method of Bradford (1).

\section{Antibody cross-reactions}

Cross-reactivity among staphylococcal toxins was analyzed by OSP (11) and enzyme-linked imunosorbent assay - ELISA (8).

\section{ELISA procedure}

Cross-reactions were analyzed adding $100 \mu \mathrm{l}$ of SEA, SEB, SEC 2 , SED or SEE in PBST to antibodycoated wells of microtitration plates. The toxin concentrations ranged from 0.25 to $8 \mathrm{ng} / \mathrm{ml}$ for SEA; 1 to $10 \mu \mathrm{g} / \mathrm{ml}$ for SEB, $\mathrm{SEC}_{2}$ and SEE, and 1.0ng to $10 \mu \mathrm{g}$ for SED. The plates were incubated at $37^{\circ} \mathrm{C}$ for 1 hour, washed five times with PBST, incubated again at $37^{\circ} \mathrm{C}$ for 1 hour and added of $100 \mu 1$ of antibody-peroxidase conjugate diluted at 1:1000 in PBST. $100 \mu 1$ of $3.3^{\prime}, 5^{\prime}$ ' $^{\prime}$ - tetramethilbenzidine solution were added to the washed plates. After 20 minutes, the enzyme reaction was stopped with $40 \mathrm{ml}$ of $2 \mathrm{M} \mathrm{H}_{2} \mathrm{SO}_{4}$ and the absorbance read at $450 \mathrm{~nm}$. 


\section{OSP method}

Three different $S$. aureus strains from Food Research Institute, Wisconsin, USA (FRI-137; FRI472; FRI-376), 17 enterotoxigenic $S$. aureus strains isolated from food handlers and 20 nonenterotoxigenic $S$. aureus were tested to measure cross-reactivity. Enterotoxigenic $S$. aureus strains from healthy food handlers producing staphylococcal enterotoxins others than SEA were kindly donated by Prof. Francisco Herrero, from University of Maringá.

\section{RESULTS AND DISCUSSION}

The four modifications of the reference scheme (Table 1) intended to reduce the number of injections and the amount of toxin necessary to obtain a titer equivalent to the reference method (12).

Comparing the titers determined by OSP method (11) using 2 and $4 \mu \mathrm{g}$ of SEA, the lower titer showed the best result, with a sharp immunoprecipitation line.

Toxicity of SEA limits the quantity of toxin to be used as initial dose and only $1 \mu \mathrm{g}$ of SEA is recommended at the first injection. Five $\mu \mathrm{g}$ may cause animal death. SEA is the most toxic staphylococci enterotoxin and classic immunization procedure allows an initial injection doses of $1 \mu \mathrm{g}$ to SEA and SEE and $10 \mu \mathrm{g}$ to SEB, SEC and SED (12). However, immunization of rabbits with high initial staphylococcal enterotoxin dose, without animal loss, was reported by Miya et al. (6).

Initial injection of 5 to $25 \mu \mathrm{g}$ of SEA did not cause the loss of any of the 13 rabbits tested (Table 1). Only the rabbit of scheme 6 , which received $25 \mu \mathrm{g}$ at initial dose (Table 1), presented significant weight loss and slow recovery, although the titer after booster dose was adequate (Table 3). This fact induces improvements in the immunization procedure, with emphasis on low number of injections.

The scheme 1 of Robbins and Bergdoll (12) resulted in the best immunization titer (Table 1), but the same was not observed after boosters (Table 3 ). Comparatively, our proposed schemes, mainly scheme 2, resulted in higher final titers, which where two to three times the titer of the reference sheme.

An efficient immunological response to SEA depends on the number of injections with high titer related to frequency and gradual increase of toxin concentration (12). Despite of this fact, scheme 2 reduced the needed number of injections, without changing the antiserum titer. The same statement was not valid for schemes 4 and 5, which used two injections for immunization and a higher SEA concentration at the initial injection (Table 1).

Investigations demonstrating action of SEA as superantigen extend other perspectives for immunization pattern and use in immune response stimulation $(2,13)$.

Table 1. Rabbit immunization schemes for production of antisera to staphylococcal enterotoxin A

\begin{tabular}{ccccccccccccccc}
\hline \multicolumn{10}{c}{ Day } \\
\hline & 0 & 3 & 8 & 21 & 24 & 28 & $59^{* *}$ & $62^{* *}$ & $63^{* *}$ & $66^{* *}$ & $67^{* *}$ & $71^{* *}$ \\
\hline Scheme & \multicolumn{10}{c}{ SEA dose $(\mu \mathrm{gg})$} \\
\hline $1 *(\mathrm{a})$ & $1^{\mathrm{a}}$ & $2^{\mathrm{b}}$ & $5^{\mathrm{b}}$ & - & $10^{\mathrm{b}}$ & $20^{\mathrm{b}}$ & - & - & $30^{\mathrm{b}}$ & $100^{\mathrm{b}}$ & - & $300^{\mathrm{b}}$ & 488 \\
$2(\mathrm{~b})$ & $5^{\mathrm{a}}$ & - & $6^{\mathrm{b}}$ & - & $20^{\mathrm{b}}$ & - & $50^{\mathrm{b}}$ & $100^{\mathrm{b}}$ & - & - & $200^{\mathrm{b}}$ & - & 381 \\
$3(\mathrm{c})$ & $10^{\mathrm{a}}$ & - & - & $25^{\mathrm{b}}$ & - & - & $50^{\mathrm{b}}$ & $100^{\mathrm{b}}$ & - & - & $200^{\mathrm{b}}$ & - & 385 \\
$4(\mathrm{~d})$ & $15^{\mathrm{a}}$ & - & - & $25^{\mathrm{b}}$ & - & - & $50^{\mathrm{b}}$ & $100^{\mathrm{b}}$ & - & - & $200^{\mathrm{b}}$ & - & 390 \\
$5(\mathrm{e})$ & $25^{\mathrm{a}}$ & - & - & $25^{\mathrm{b}}$ & - & - & $50^{\mathrm{b}}$ & $100^{\mathrm{b}}$ & - & - & $200^{\mathrm{b}}$ & - & 400 \\
\hline
\end{tabular}

* Reference procedure of Robbins and Bergdoll (12)

** Booster injections

${ }^{a}$ SEA emulsified in complete Freund's adjuvant

${ }^{b}$ SEA emulsified in incomplete Freund's adjuvant

(a) two rabbits; (b) five rabbits; (c) three rabbits; (d) four rabbits; (e) one rabbit. 
Table 2: Antiserum titers after immunization

\begin{tabular}{ccccc}
\hline \multirow{2}{*}{ Scheme } & & & \multicolumn{2}{c}{ Titer* } \\
\cline { 4 - 5 } 1 & Rabbits & Total SEA $(\mathrm{g})$ & $2 \mathrm{~g} \mathrm{SEA} / \mathrm{ml}$ & $4 \mathrm{~g} \mathrm{SEA} / \mathrm{ml}$ \\
\hline & A & & 32 & 16 \\
& B & 38 & 32 & 16 \\
2 & A & & 32 & 12 \\
& B & & 8 & 4 \\
& C & 31 & 8 & 4 \\
& D & & 16 & 8 \\
3 & E & & 8 & 4 \\
& A & & 4 & 2 \\
& B & 35 & - & - \\
& C & & - & - \\
4 & A & & 32 & 16 \\
& B & 40 & - & - \\
& C & & 8 & 4 \\
& D & & - & - \\
\hline
\end{tabular}

SEA emulsified in complete (first dose) and incomplete (subsequent doses) Freund's adjuvant.

* As determined by OSP (Optimun Sensitivity Plate)

Table 3: Antiserum titers after booster

\begin{tabular}{|c|c|c|c|c|}
\hline \multirow[b]{2}{*}{ Scheme } & \multirow[b]{2}{*}{ Rabbits } & \multirow[b]{2}{*}{ Total SEA (g) } & \multicolumn{2}{|c|}{ Titer* } \\
\hline & & & $2 \mathrm{~g} \mathrm{SEA} / \mathrm{ml}$ & $4 \mathrm{~g} \mathrm{SEA} / \mathrm{ml}$ \\
\hline \multirow[t]{4}{*}{1} & A & $450^{\mathrm{a}}$ & 48 & 24 \\
\hline & B & & 40 & 20 \\
\hline & A & & 120 & 60 \\
\hline & B & & 60 & 30 \\
\hline \multirow[t]{4}{*}{2} & $\mathrm{C}$ & $350^{\mathrm{a}}$ & 60 & 30 \\
\hline & D & & 60 & 30 \\
\hline & E & & 40 & 20 \\
\hline & A & & 60 & 30 \\
\hline \multirow[t]{3}{*}{4} & B & $350^{\mathrm{a}}$ & - & - \\
\hline & C & & - & - \\
\hline & $\mathrm{D}$ & & - & - \\
\hline 5 & A & $350 \mathrm{a}$ & 48 & 20 \\
\hline
\end{tabular}

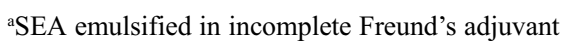

* As determined by OSP (Optimun Sensitivity Plate)

Animals of scheme 3 were discarded and the booster dose was not given because results of immunization were inadequate (Table 3 ). Rabbits of scheme 4 were discarded after the booster dose because there was no response in three out of four animals.

Rabbits of scheme 2 received $100 \mu \mathrm{g}$ less SEA than those of the reference method but reasonable titer was achieved with a reduced number of injections.

Fig. 1 confirms the excellence of scheme 2 for antiserum production, which was equivalent to the method of Robbins and Bergdoll (12).

The cross-reactivity of crude antiserum with

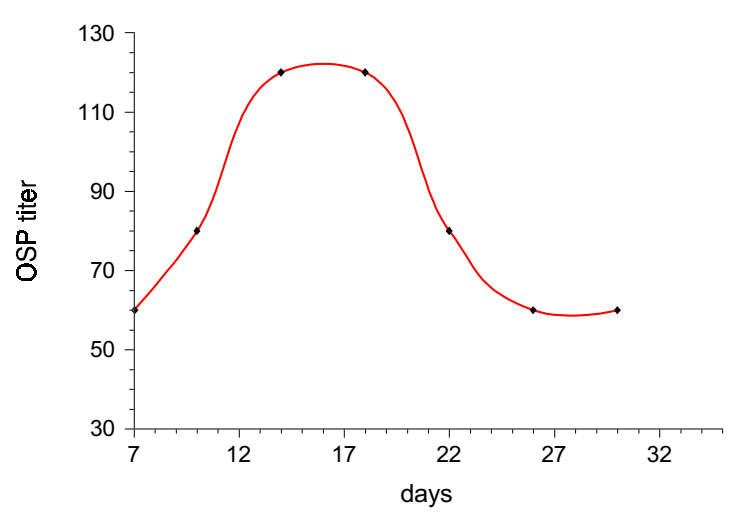

Figura 1. Antibody response in rabbit $2 \mathrm{~A}$ after booster of $350 \mu \mathrm{g}$ of SEA

other staphylococcal enterotoxins was analysed by OSP and by ELISA-sandwich method using purified IgG (data not shown). In OSP method, the specificity of crude antiserum was enough to avoid identity or partial identity precipitation against culture supernatant of $S$. aureus strain SFRI-137 (SEC1) 472 (SED) and 326 (SEE). An intense inespecific precipitation line with anti-SEA, observed with SED-producing strain 472, disappeared after absorbing the supernatant, indicating inespecific reaction with protein $\mathrm{A}$. The crude polyclonal anti-SEA did not cross-react with 20 non-enterotoxigenic $S$. aureus strains and 17 other enterotoxin producing strains.

In ELISA-sandwich method, using IgG purified by protein $\mathrm{A}$, the amounts of toxin required for $\mathrm{OD}_{450}=0.5$ were: SEA, $2.5 \mathrm{ng} / \mathrm{ml}$; SED, $6.7 \mu \mathrm{g} / \mathrm{ml}$; $\mathrm{SEC}_{2}, 3.4, \mu \mathrm{g} / \mathrm{ml}, \mathrm{SED},>10 \mu \mathrm{g} / \mathrm{ml}$; SEE, $>10 \mu \mathrm{g} / \mathrm{ml}$. The highest cross-reaction was observed with $\mathrm{SEC}_{2}$. However, the occurrence of cross-reactions was less than $0.1 \%$.

In conclusion, scheme 2 was adequate to produce specific SEA antisera, with high titers. In addition to the lower amount of toxin required for immunization, the proposed procedure also requires a lower number of injections when compared to the reference method. High titers of antibodies were achieved in all rabbits after booster. The polyclonal antibody was satisfactory as reagent in OSP and the purified IgG was used in ELISA without crossreactions with other staphylococcal enterotoxins.

\section{ACKNOWLEDGEMENTS}

The authors would like to thank $\mathrm{CNPq}$ for fellowships and financial support. 


\section{RESUMO}

\section{Produção e purificação, a baixo custo, de anticorpos policlonais para enterotoxina estafilocócica A}

O objetivo principal deste trabalho foi propor um esquema de imunização para a produção de anticorpos para a enterotoxina estafilocócica A (EEA). O método de referência preconizado por Robbins e Bergdoll foi modificado visando a redução do número de doses e da quantidade de toxina administrada por animal. $\mathrm{O}$ melhor esquema de imunização empregou doses de 5, 6, 20, 50, 100 e $200 \mu \mathrm{g}$ de EEA administradas a intervalos de 0,8 , 24, 59, 62 e 67 dias, respectivamente. Esse esquema empregou um total de $381 \mu \mathrm{g}$, equivalente à redução de $107 \mu \mathrm{g}$ de EEA, em relação ao método de referência. $\mathrm{O}$ título médio do anti-soro utilizando a técnica de Optimum Sensitivity Plate - OSP foi de 1:60 e de ELISA 1:100.000. A ausência de reações cruzadas com outras enterotoxinas estafilocócicas, observada nas técnicas de OSP e ELISA, indicou alta especificidade do anticorpo para EEA, com a vantagem da redução da quantidade de toxina purificada necessária para a imunização.

Palavras-chave: Staphylococcus aureus, detecção, enterotoxinas, imunização

\section{REFERENCES}

1. Bradford, M.M. A rapid and sensitive method for the quantification of microgran quantities of protein utilizing the principle of protein biding. Anal. Biochem., 72:248-254, 1976.

2. Chatila, T.; Geha, R.S. Superantigens. Curr. Op. Immunol., 4:74-78, 1992
3. Evenson, M.L.; Hinds, M.W.; Bernstein, R.S.; Bergdoll, M.S Estimation of human dose of staphylococcal enterotoxin A from a large outbreak of staphylococcal food poisoning involving chocolate milk. Int. J. Food Microbiol., 7:311-316, 1988.

4. Herrero, F. Estafilococos enterotoxigênicos em portadores assintomáticos: isolamento e efeito de oxacilina na produção de proteínas extracelulares de interesse em alimentos. 1992 (Tese de Mestrado - Universidade Estadual de Londrina, Paraná).

5. Kraatz-Wadsack, G.; Ahrens, W.; Von Stuckrad, J. ELISA screening of staphylococcal enterotoxins by means of a specially developed test kit. Int. J. Food Microbiol., 13:265272, 1991

6. Miya, N.T.; Salzberg, S.P.; Pereira, J.L. Método rápido de imunização de coelho para obtenção de anti-soros de enterotoxinas estafilocócicas. resumo. v.1 III Mostra Interna de Trabalhos em andamento na FEA/UNICAMP, 1992

7. Morissette, C.; Goulet, J.; Lamoureux, G. Simple and rapid inhibition enzyme immunoassay for the detection of staphylococcal enterotoxin B in foods. J. Food Prot., 53:834840,1990

8. Oliveira, T.C.R.M. Produção de reagentes imunológicos para detecção de enterotoxina estafilocócica A em alimentos.1994 (Tese de Doutorado - Universidade Estadual de Londrina, Paraná).

9. Park, C.E.; Akhtar, M.; Rayman, M.K. Evaluation of commercial enzyme immunoassay kit (RIDASCREEN) for detection of staphylococcal enterotoxins A, B, C, D and E in foods. Appl. Environ. Microbiol., 60:677-681, 1994.

10. Park, C.E.; Akhtar, M.; Rayman, M.K. Nonspecific reactions of a commercial enzyme-linked immunosorbent assay kit (TECRA) for detection of staphylococcal enterotoxins in foods. Appl. Environ. Microbiol., 58:2509-2512, 1992.

11. Robbins, R.; Gould, S.; Bergdoll, M. Detecting the enterotoxigenicity of Staphylococcus aureus strains. Appl. Microbiol., 28:946-950, 1974.

12. Robbins, R.; Bergdoll, M.S. Production of rabbit antisera to the staphylococcal enterotoxins. J. Food Protec., 47:172-176, 1984

13. Swaminathan, S.; Furey, W.; Pletcher, J.; Sax., M. Crystal structure of staphylococcal enterotoxin B, a superantigen. Nature, 359:801-806, 1992.

14. Wieneke, A.A. Comparison of four kits for the detection of staphylococcal enterotoxin in food from outbreaks of food poisoning. Int. J. Food Microbiol., 14:305-312, 1991.

15. Windermann, H.; Lüthy, J.; Maurer, M. ELISA with enzyme amplification for sensitive detection of staphylococcal enterotoxins in food. Int. J. Food Microbiol., 8:25-34, 1989. 